\title{
NONPROFIT SZEKTOR A KISVÁROSOKBAN
}

\author{
(Nongovernmental Sector in Villages) \\ BUCHER ESZTER - PIRISI GÁBOR
}

\begin{abstract}
Kulcsszavak:
nonprofit szervezetek helyi társadalom kisváros differenciálódás

A tanulmány célja, hogy bemutassa a nonprofit szektor jelenlétét a kisvárosok szintjén. Az itt közölt eredmények részét képezték egy átfogó vizsgálatnak, melynek célja a hazai kisvárosok differenciálódásának elemzése volt. A nonprofit szektor önálló vizsgálata ennél a településtípusnál azért tünik különösen indokoltnak, mert a jól szervezett helyi társadalom a kisvárosok legfontosabb sajátossága, egyben egyik potenciális eröforrása. A dolgozatban néhány rendelkezésre álló adat segítségével próbálunk átfogó képet adni a vizsgált sajátosságok eloszlásának földrajzi és egyéb, például a funkcionális típusokra visszavezethetö okairól.
\end{abstract}

A rendszerváltozás óta eltelt két évtized alatt a nonprofit szektor jelentős számbeli gyarapodáson és minőségi fejlődésen ment keresztül, de a helyét a magyar társadalomban még ma is keresi. Az országban az 1980-as és 1990-es évek fordulóján végbement politikai, gazdasági és társadalmi átalakulás megnyitotta az utat a civil szféra kibontakozása előtt, a korábbi gátak megszünésével a fejlődés robbanásszerü volt. Egyre erősebben nyilvánultak meg azok a jelenségek, amelyek közösségi választ adtak a problémákra, szükségletekre. A nonprofit szektor létrejöttének egyik legfontosabb oka, hogy olyan új társadalmi igények jelentek meg, amelyeket sem az állami, sem a piaci szektor nem tudott biztosítani. A korábbi mindenható és gondoskodó állam visszaszorulásával nem csak igény, hanem szükség is volt a társadalom önszerveződéseinek egyre szélesebb tevékenységi kört felölelő feladatvállalására. Hazánkban a rendszerváltozást követően az állampolgároknak lehetőségük van arra, hogy közösségek formájában meghatározó szereplőivé váljanak a településeiket és térségeiket érintő feladatok alakításában (Kuti 1996).

A társadalmi szerveződések számos olyan pozitív tulajdonsággal rendelkeznek, melyek indokolttá teszik szerepüket települések életében. A civil szervezetek az állami, a piaci szektor és a társadalom tagjai között összekötő funkciót töltenek be, érdekérvényesítésre, -képviseletre képesek, hosszú távú jövőképpel, jelentős szabad kapacitással bírnak és emellett olyan helyismereti és kapcsolati tőkével rendelkeznek, melyek pótolhatatlanná teszik őket a helyi ügyek szervezésében, a térségeiket érintő fejlesztésekben (Bucher 2008). A szervezetek müködésük révén egyfajta öntudatos polgárságot nevelnek, mely közösség a civil kontrollt testesíti meg. A nonprofit szervezetekben való tevékenység az egyént egy közösség aktív és felelős tagjává teszi, erősíti az emberek között lévő társadalmi köteléket, a szolidaritás, a kölcsönösség képességének kialakulását (Habermas 1993). Az élhető környezet kialakításában a cél a társadalmi szereplők közötti együttmüködés, melyet az Európai Unió is támogat. 
A decentralizáció, nyilvánosság, részvétel, partnerség és a szubszidiaritás elvek a civil szervezetek bevonását segítik a területi, települési problémák megoldásába.

A nonprofit szervezetek több mint fele települési szinten müködik. A civil szervezetek napjainkra sokszínü, önálló társadalmi és gazdasági erővel bíró szereplőként jelentek meg minden település típus esetén (Nárai 2003). A település lakosságának érdekeit, céljait, az alulról jövő kezdeményezéseket képviselik, így ezek a közösségek együttmüködő partnerei lehetnek a települési önkormányzatoknak. A települések a különféle érdekek megnyilvánulásának szinterei. A terület- és településfejlesztés céljaiban különböző helyi kezdeményezésű csoportok, az állam, az önkormányzat és a vállalkozók érdekei találkoznak és ütköznek (László-Köszegfalvi 2007). A társadalmi-politikai innovációk között kiemelkedő jelentősége van a civil társadalom szervezeteinek, azok számának, gyarapodásának a településhálózat egyes szintjein (Rechnitzer 1998).

Tevékenységük és szerepük talán a leghangsúlyosabban a kisvárosok esetében jelenik meg, hiszen ez az a településméret, amely a köztes szerepet tölti be a községek és a nagyobb lakosságszámmal bíró közép- és nagyvárosok között. A vizsgált településkategóriát leginkább a helyi társadalmával jellemezhetjük, hiszen itt az élettér, a társadalmi hálók nem szűkültek be, az emberek mindennapi kapcsolatban állnak egymással, kölcsönös a bizalom, az emberek ismerik egymást, az együttmüködési hajlandóságuk magas. Sok esetben rendelkeznek a falvakra jellemző személyes jellegü, családi, rokonsági, szomszédsági, baráti viszonyokkal (Tönnies 1983), ugyanakkor a városokhoz hasonlóan a szélesebb körü munkamegosztás, változatos társadalomszerkezet és a szolgáltatások széles palettája jellemzi őket.

A kisváros az átlátható léptékben szerveződő polgári közösségek által meghatározott urbánus településként él a köztudatban. Mindenképpen olyan településtípusként, ahol a méret még nem zárja ki azt, hogy a személyes kapcsolatokon alapuló szociális hálózatok teljesen átfogják a helyi elit tagjait, és ahol az egyéni vagy közösségi kezdeményezéseken alapuló civil aktivitás milyensége, sikeressége jelentős mértékben képes befolyásolni a település fejlődésének irányát és sebességét.

Más szempontból, a kisvárosokat a közgondolkodás is igen gyakran tekinti a tradicionalitás, sok szempontból a provincializmus, vagy - pozitívabb megítélés esetén - a hagyományos értékekhez való ragaszkodás településeinek. Éppen ezért adódik a hipotézis, hogy akár a kapcsolatok belátható dimenziói, akár az értékalapú közösségi szerveződések oldaláról közelítünk is, a civil aktivitást az átlagosnál jelentősebbnek vélhetjük ebben a településkategóriában.

Nagyon nehéz pontosan meghatározni, mely településeket tekinthetünk kisvárosnak. E tanulmány társszerzője arra, a már több helyen (Pirisi 2009a; 2009b) viszonylag részletesebben kifejtett álláspontra helyezkedett, hogy a kisvárosokat csak saját földrajzi környezetük, genetikai és funkcionális különbözőségük, valamint lakosságuk életmódjának figyelembevételével lehet a hazai viszonyok között érvényes közös definíció alá rendelni. Ennek megfelelően kisvárosokként a környezetükből társadalmi és/vagy gazdasági és infrastrukturális elemek sürüsödésével kiemelkedö, városias életformát kínáló, önmagukat városként definiáló településeket tekintjük. 
Fontos azonban leszögezni, hogy a hazai városállomány értékelésekor jelentős szerepet játszik a percepció maga: ha európai vagy akár globális nézőpontból indulunk ki, akkor egyetlen nagyvárosunkat néhány, regionális funkciókat betöltő európai középváros és számos kisváros követi a hálózatban. Ha a hazai településrendszert önmagában vizsgáljuk, akkor a kategóriák eltolódnak, és regionális központjaink nagy, megyeszékhelyeink és talán néhány megyei társszerepköröket betöltő település középvárossá válnak. Ebben az olvasatban a kisvárosnak a kistérségi szintủ szerepkörök felelnek meg. Nagy a bizonytalanság a tekintetben is, hogy hol a kisvárosiasság határa „lefelé”, létezik-e, vagy megkülönböztethetö-e még egy „„örpevárosi” (Dövényi 2008) vagy „,faluvárosi” (Beluszky-Györi 2006) kategória?

Utóbbi kifejezés már hangzásában is utal a hazai kisváros-állomány - húzzuk is meg bárhol a határait - egy másik sajátosságára. Nevezetesen, hogy a méretük és területi szerepköreik alapján kétségkívül ide tartozó települések genetikai és funkcionális értelemben jelentős heterogenitást mutatnak, és ezen heterogenitáson belül a tradicionális, központi szerepkörökön alapuló polgárias fejlődést befutó, némi leegyszerüsítéssel „dunántúlinak" nevezhető típus csak egy a sok közül. Noha a különbségek a szocializmus évtizedeiben halványodtak, de attól még az eltérő fejlődési pálya hatásai kimutathatók az ebbe a kategóriába sorolható mezővárosi gyökerekkel rendelkező településeken, illetve az ennél is jelentősebb eltéréseket mutató, ipari hátterü, gyorsított ütemben megteremtett városokon, továbbá az idegenforgalom, vagy a szuburbanizációs folyamat révén kiemelkedett helyeken. Tovább fokozódik a sokszínüség, ha a városiasság határeseteit, a legutóbbi években várossá nyilvánított, sok esetben kis méretü és szerény funkciókörrel rendelkező településeket is ebbe a csoportba soroljuk. Éppen ezért, a kisvárosok civil aktivitásának vizsgálata nem képzelhető el anélkül, hogy megkíséreljünk feltárni néhány, a településcsoporton belül megjelenő törésvonalat.

\section{A kutatás módszertana}

A kutatás szempontjából az egyik legfontosabb probléma a vizsgálandó kisvárosok körének meghatározása volt. A fentiekben már részben érintettük a lehatárolással kapcsolatos problémák egy részét, vagyis hogy a kisvárosok köre mindenképpen csak jelentős bizonytalansággal határozható meg, nincs szakmai konszenzus sem az alsó, sem pedig a felső küszöb tekintetében. Magunk úgy döntöttünk, hogy a korábbi kutatások során már alkalmazott határokat vonjuk meg újra, vagyis a vizsgálat során kisvárosnak tekintünk minden olyan települést, amely városi ranggal rendelkezik, és amelynek lakónépessége a 2008-as T-STAR adatok szerint nem több 30 ezer fönél. Ez összesen 289 település bevonását jelentette.

Sajnos, a nonprofit aktivitás átfogó vizsgálatához igen csekélyek a nyilvános adatbázisok által nyújtott lehetőségek. A települési bontásban lényegében csak a regisztrált nonprofit szervezetek száma áll rendelkezésre, 1999-től évenként. Azonban nem ismert, hogy ezek közül mennyi a valóban müködő, illetve mennyi a be nem jegyzett, de létező civil kezdeményezés. A KSH nonprofit statisztikáiban rendel- 
kezésre álló, több alkalommal feldolgozott források nem teszik lehetővé kisvárosokra vonatkozó következtetetések levonását, illetve az egyes települések és településcsoportok összehasonlítását.

\section{A statisztikai elemzés}

A vizsgált közel 300 kisváros természetesen meglehetősen heterogén képet mutat. Lakosságszámuk a félszáz fő híján harmincezres Kazincbarcikától az alig 1073 embernek otthont adó Pálházáig terjed. Együttes lakosságszámuk közel 2,7 millió fő volt 2008-ban, és 2,73 millió 1999-ben, vagyis dacára a csoportba tartozó számos igen dinamikus település népességnövekményének, összességében már a fogyatkozás jellemzi a kisvárosokat, holott az 1990-es és 2001-es népszámlások között eltelt időben még gyarapodott népességük, szemben a városállományunk nagyobb méretü tagjaival.

A kisvárosok 2008-ban 17835 bejegyzett nonprofit szervezet székhelyét mondhatták magukénak az országszerte müködő 79 003-ból (Forrás: T-STAR). Ez 22,57\%-os arányt jelent, ami, már első pillanatban cáfolni látszik a kisvárosok civil társadalmának szervezettségére vonatkozó előzetes feltételezéseinket, hiszen mintegy 4,5\%-kal alacsonyabb a népesség arányuknál. Ebböl a szempontból bizony a kisvárosok a községekkel mutatnak hasonlatosságot. Budapest és a megyei jogú városok ugyanis felülreprezentáltak (előbbi kategória közel hét, utóbbi négy százalékponttal), a mindössze 15 elemet számláló „középvárosi” kategória esetében a két arány közel azonos, míg a községek (beleértve a nagyközségeket is) a 30\%-nyi népességarány mellett csak 24,5\%-ot mondhatnak magukénak a nonprofit szervezetekböl.

Érdekes, hogy a fenti arányok meglepően állandónak bizonyulnak. Az elérhető legkorábbi, 1999-es adat most már lehetőséget teremt arra, hogy közel egy évtizednyi távlatban végezzünk összehasonlítást: azt találjuk, hogy eközben ugyan a regisztrált szervezetek száma országosan mintegy egynegyedével nőtt, a kisvárosok részesedés akkor is $22 \%$ volt. Némi átrendeződés végbement ugyan, hiszen a községek jelentősége valamelyest nőtt, a megyei jogú városoké csökkent (2-2\%-ról van szó), mégis megállapítható, hogy a civil szféra településhálózati konfigurációja meglepőn stabilan kialakult, és a kisvárosok ezen belül is stabil elemnek számítanak.

A vizsgált kisvárosok mindegyikének van bejegyzett nonprofit szervezete, a legkevesebb, nyolc darab a Somogy megyei Igalban található (egyik legújabb és egyik legkisebb városunk is egyben). Egyébként, összesen 225 olyan település van, ahol egyáltalán nincs regisztrált szervezet, és ezek közül is Ipolyszög a legnagyobb a maga 643 lakosával. Így nyugodtan elmondhatjuk, hogy a civil társadalom formális megszerveződése nem városi küszöbfeltétel: a határ valamivel a mai, rendkívül leszállított várossá nyilvánítási határ alatt húzódik, és tulajdonképpen a törpe-, valamint az aprófalvak egy részét leszámítva meglehetősen általános jelenség hazánkban.

A fentiekből egyébként az következne, hogy minél nagyobb egy település, annál több nonprofit szervezet müködik benne, nem csak abszolút, hanem relatív értelem- 
ben is, hiszen az előbbiekben bemutatott arányok a településhierarchiában felfelé haladva növekedtek. Éppen ezért tarjuk némileg meglepőnek, és a kisváros-állomány belső differenciáltságára utaló jelnek, hogy ez az összefüggés a kisvárosok csoportján belül nem állja meg a helyét. A népesség és az ezer före vetített szervezetszám között egyáltalán nem mutatható ki kapcsolat (a korrelációs együttható értéke -0,096). Úgy tünik, adott településtípuson belül valamilyen más magyarázó tényezőt kell keresnünk.

Az ezer lakosra jutó szervezetszám átlaga a kisvárosokban 2008-ban 6,61 volt. Emögött azonban kifejezetten jelentős különbségek húzódnak meg (1. ábra).

\section{1. ÁBRA}

1000 lakosra jutó nonprofit szervezetek száma a kisvárosokban (2008)

(Number of Nongovernmental Organisations per 1000 Inhabitants in Villages,

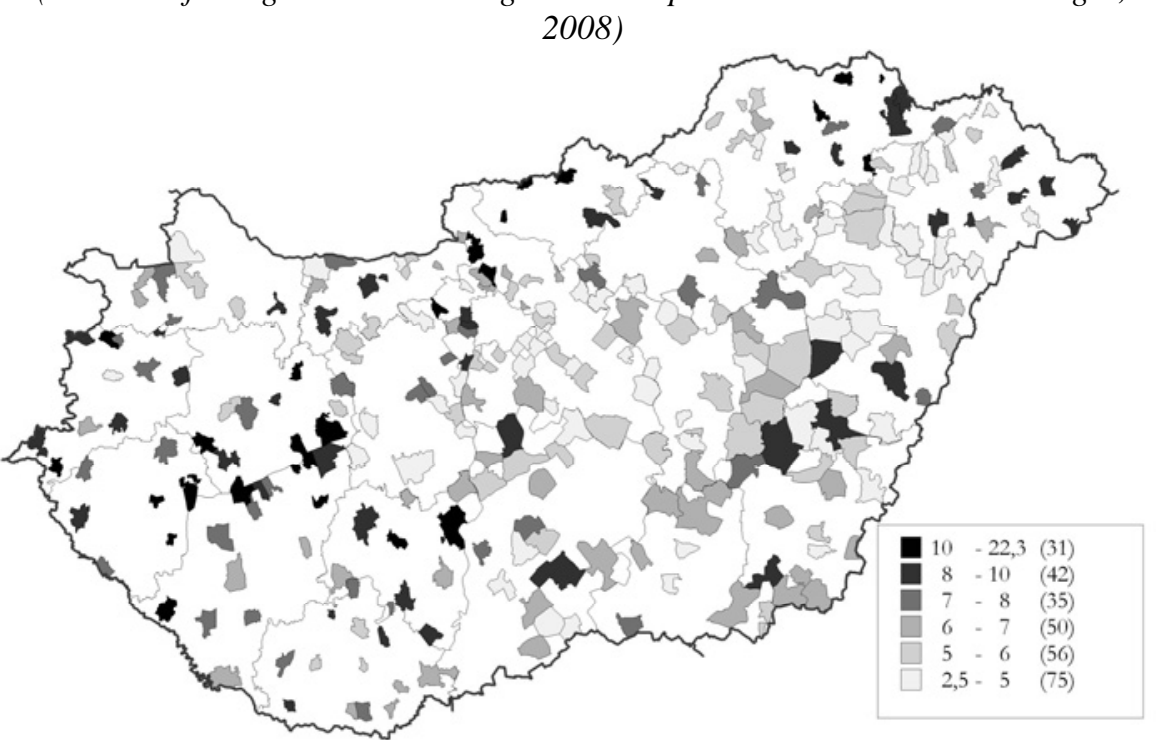

Forrás: Saját szerkesztés.

A területi mintázat csak részben vezethető le az általános értelemben vett regionális térszerkezetből. A legmagasabb értékekkel jellemezhető kisvárosok között találjuk szinte az összes Balaton-parti üdülőtelepülést, a budapesti agglomeráció nyugati és északi szektorának kisvárosait (Zsámbék, Budaörs, Szentendre, Visegrád). Vannak olyan, fejlett civil szférával jellemezhető kisvárosok, ahol ugyan a térség általános társadalmi-gazdasági fejlettsége meglehetősen alacsony, de az urbánus hagyományok viszonylag jelentős múltra tekinthetnek vissza (Sárospatak, Sátoraljaújhely, Tokaj és néhány más zempléni város, továbbá Nógrádból Balassagyarmat, Szécsény). Más esetekben nehéz egyértelmü magyarázatot adni. Szabolcs-Szatmár-Bereg megyében Vásárosnamény, Fehérgyarmat, Csenger és Mátészalka nem csak a civil szervezetek tekintetében emelkedik ki (Pirisi 2009a), de ezzel együtt meglepő jó szereplésük. Tolna megyében Paks esetében a mezővárosias polgári fejlődést felváltotta egy iparvárosi pálya, de szemben a többi hasonló sorsú kisvárossal itt igen jelentős a diplomások 
részaránya. Gyönk, Tamási, Bonyhád és Bátaszék azonban általában nem tekinthető fejlett kisvárosoknak, mégis úgy tünik, Tolna megye vizsgált településeire majdnem egyöntetüen jellemző az átlag feletti szervezetszám. Szintén viszonylag egyveretü, pozitív értelemben Vas és Zala megye is: ezen belül ugyanakkor általában nem azok a városok emelkednek ki, amelyekre számítanánk (pl. Szentgotthárd és Vasvár jobban teljesít Körmendnél, Répcelak és Csepreg Sárvárnál stb.). Nagyon érdekesek a lokális törésvonalak: Borsod-Abaúj-Zemplén megye eltérő történelmi utat bejáró nyugati (borsodi) és keleti zempléni része között, a budapesti agglomeráció budai és pesti oldalán, Fejér megye északi és déli részének kisvárosai között.

\section{2. ÁBRA}

Az 1000 lakosra jutó nonprofit szervezetszám változásának aránya a kisvárosokban 1999 és 2008 között

(The Rate of Changes in the Number of Nongovernmental Organisations per 1000 Inhabitants in Villages between 1999 and 2008)

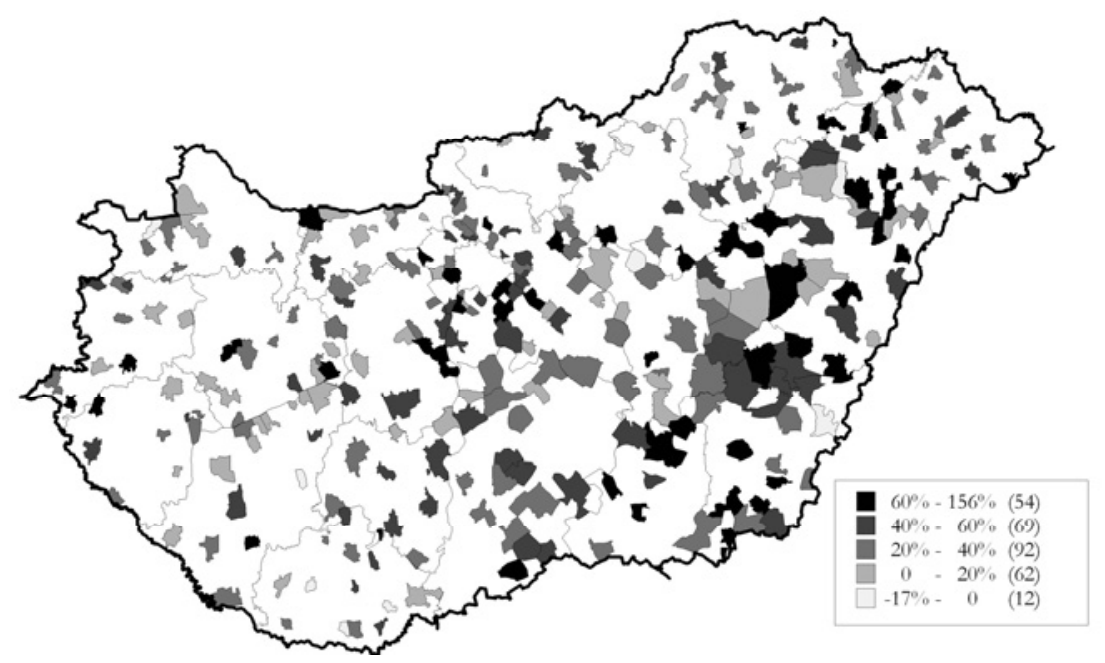

Forrás: Saját szerkesztés.

Ha összehasonlítjuk a 2. ábra változás-térképét az 1. ábra jelenlegi eloszlásával, akkor feltünő, hogy a folyamatok a kiegyenlítődés irányába mozdulnak el. Mindez természetesen egy általános növekedési tendencia mellett figyelhető meg, mindössze 12 olyan kisváros van, ahol a szervezetszám fajlagos értéke csökkent. Ezek között tulajdonképpen nem lehet közös pontot találni, akár földrajzi, akár egyéb tényezőket nézünk, úgy tünik, esetleges, helyi tényezőkkel magyarázható történéssel állunk szemben. Az viszont egyértelmü, hogy a korábban alacsonyabb szervezetszámmal jellemzett kisvárosok produkálták az intenzívebb növekedést: így elsősorban az alföldi települések és az agglomeráció déli-keleti szektorai emelhetők ki. A két csoport között az az alapvető különbség, hogy előbbi csökkenő, utóbbi viszont igen intenzíven növekvő népesség mellett volt képes jelentősen növelni a nonprofit aktivitást. Hasonlóképpen: az 1. ábrán magas fajlagos értékekkel jellemzett, jól körül- 
írható csoportok közül például a Balaton-parton és ÉK-Magyarországon is aránylag mérsékelt a növekedés. Ezek alapján úgy tünik, hogy a kisvárosi nonprofit szektor kiépülésének innovációs hulláma lassan halad a perifériák felé, és a fejlettebb térségekben hamarosan elérhet egyfajta telítettséget.

Mindazonáltal, ezzel a következtéssel magunk részéről óvatosan bánnánk. Első intő jel, hogy a leginkább kiemelkedő mértékü gyarapodást abszolút értelemben Budaörs és Szentendre civil szektora érte el, vagyis két eleve igen fejlett és polgárosodott kisvárosé. Szentendre időközben a 14.-ről a 10., Budaörs a 138.-ról (!) a 33. helyre lépett elöre az 1000 före számított rangsorban.

A statisztika sem támasztja alá a területi szinten kibontakozó konvergenciáról alkotott elsődleges véleményünket. Az 1999-es mintában az átlagos eltérés mértéke 1,64, a 2008-asban már 2,00, a két év között a minták szórása 27\%-kal emelkedett. A két szélső érték közötti különbség ugyan csökkent (1999-ben 11,3-szoros, 2008-ban 8,8-szoros), de itt érzésünk szerint kicsit csalókák a számok, hiszen Hajdúsámson (stabil utolsó) szó szerint 1-röl a kettőre jutott (1,518 - 2,5), míg az élen a növekedés, ha arányaiban nem is, abszolút értékben jelentősebb volt (17,2 - 22,2, Visegrád - Öriszentpéter).

Mely tényezők magyarázzák ezeket a jelentős eltéréseket? Pusztán a földrajzi elemzés is rávilágított arra, hogy meglehetősen komplex kérdéssel állunk szemben. A települések helyzetét leginkább leíró lehetséges mérőszámok közül a nonprofit szervezetek száma nem mutat szoros korrelációt $(0,249)$ a vállalkozások (ezer före jutó) számával, sem pedig a település státuszára komplex módon utaló migrációs különbözettel $(0,057)$. Szorosabb a kapcsolat a település polgárainak vagyonát jelző személygépkocsi-számmal $(0,385)$, de szinte egyáltalán nincs az álláskeresők lakosságon belüli arányával $(-0,11)$, bár legalább a várakozásoknak megfelelően fordított az összefüggés. A legszorosabb kapcsolat a diplomások arányával (2001-es adatok szerint) mutatható ki, itt az együttható értéke 0,544. Nyilván a diplomások soraiban inkább feltételezzük az önszerveződéshez szükséges kurázsit, aktivitást. De hat ez a tényező a jövedelmi viszonyokra is, hiszen ezen a szinten az egy före jutó szjaértékek és a diplomások jelenléte között szoros az összefüggés (Pirisi 2009b).

Ha ezeket a tényezőket megpróbáljuk összegezni, akkor végeredményként ugyanaz sejlik fel, mint ami a földrajzi elemzés kapcsán már megfogalmazódott: a jobb gazdasági helyzetü és funkcionális értelemben is fejlettebb kisvárosokat általában jobban kiépült nonprofit szektor jellemzi, hasonló következtetést vont le Rechnitzer János (1998) és Kákai László (2009) is. Utóbbi tényezőt elsősorban azért érdemes figyelembe venni, mert ebben a rendkívül heterogén kisvárosi mezőnyben a diplomások átlag feletti jelenléte vagy a szuburbanizációhoz köthető (ld. a korábban már említett Szentendre példáját), vagy az üdülőtelepüléseken jellemző (ami gyökerét tekintve hasonló folyamat eredménye, némi túlzással talán dezurbanizációnak is tarthatnánk), illetve azokban a kisvárosokban meghatározó, amelyek fejlett intézményi körrel emelkednek ki a környezetükből (praktikusan az egykori járási székhelyek többségéröl van szó). 
A kisvárosi nonprofit jelenlét különböző jellegzetességeit vizsgálva felhasználtuk azokat a típusokat, amelyeket a korábban említett kutatások eredményeiként határoztunk meg. Ennek érdekében a két felhasznált mutatót (1000 lakosra jutó szervezetszám 2008-ban, illetve annak változása 1999 és 2008 között, a kiinduló év arányában) az egyes típusokra nézve összegeztük. A 3. ábrán a koordináta-tengelyek metszéspontját a teljes kisvárosi minta átlagára pozícionáltuk, továbbá feltüntettük az egyes típusokhoz tartozó átlagos település helyét is, a típushoz tartozó összes települést pedig egy-egy vonallal határoltuk: ez utóbbit tüntettük fel az ábrán.

\section{3. ÁBRA}

Nonprofit szervezetek száma és annak változása az egyes kisváros-típusokban (The Number of Nongovernmental Organisations and its Changes in Different Village-types)

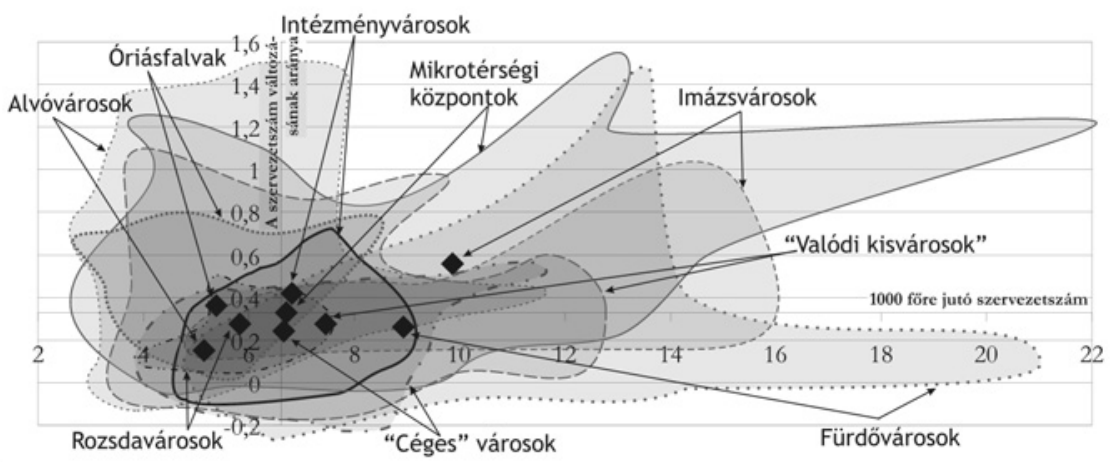

Forrás: Saját szerkesztés.

Az talán ezen a meglehetősen bonyolult rajzon is elkülöníthető, hogy vannak az átlagtól határozott pozitív vagy negatív eltérést mutató csoportok. Elsősorban az $\mathrm{x}$ tengely, vagyis a 2008-as szervezetszám mentén erőteljes a differenciálódás. Az is látszik, hogy milyen jelentősek a kiugrások, vagyis az a - valójában egy-egy - extrém értékeket mutató település, amely távol esik még a hozzá hasonlóak körétől is. Így a fürdővárosokat Visegrád, a mikrotérségi központokat Öriszentpéter húzza felfelé. Ugyanígy az y, vagyis a változás ütemét kifejező tengely mentén Nagymányok és Pálháza ugrik ki. Egy közös pont van a fenti négy településben: valamennyi a kisvárosok csoportján belül is inkább a „törpe” méretkategóriába sorolható, egyik sem nagyobb 3000 fősnél, nyilván itt az értékek fajlagos jellege miatt viszonylag jelentősek a torzulások: 4-5 nonprofit szervezet létrejötte Pálházán már kiugró arányú változás.

Mindenesetre a típusokhoz tartozó átlagok kifejezőbbek az egyes extremitásoknál. Az imázs- és fürdővárosok határozottan több szervezettel rendelkeznek (megint csak óvatosságra int ezen települések jellemzően szerény mérete). A fürdővárosok esetében több komponens, a jövedelmek és a diplomások magas aránya miatt ez nem is meglepő. Az imázsvárosok esetében pedig alátámasztja a településtípus eredeti koncepcióját (Pirisi-Trócsányi 2006), amennyiben olyan kisvárosokról van szó, ahol a hely szelleme meghatározó, városképző erővel bír, ahol a településnév termékhez, termékcsoportokhoz kapcsolódó márkanév is egyben. 
A negatív irányban tapasztalható eltérések három olyan településcsoportnál merülnek fel, amelynek urbanizációja sajátos jegyeket mutat. Az óriásfalvak esetén (amelyek jellemzően az átlagosnál gazdasági és szükebben vett társadalmi értelemben is fejletlenebbek) az agrárgazdaság városi mértéket meghaladó súlya volt a fő csoportképző faktor, így nem váratlan az elsősorban a polgárosodáshoz kapcsolódó civil aktivitás szerényebb mértéke. Hasonló a helyzet az - egykori leépült nehézipari hagyományokkal, ,szocialista” múlttal rendelkező, strukturális válságtól sújtott rozsdavárosok esetén: a polgárosodás itt is láthatóan elmaradt az urbanizáció üteme mögött, ráadásul a most már két évtizede tartó válság szelektíven erodálta a települések meglévő humán erőforrásait is, jelentős elvándorlást váltva ki elsősorban a mobilisabb, diplomás rétegek körében. Az alvóvárosok - ebbe a csoportba a klasszikus szuburbán településeken kívül belekerültek olyan kisvárosok is, amelyek érdemi központi funkció nélkül, relatív népességkoncentrációjuk révén emelkednek csak ki a környező térségből - gyengébb értékei megint csak azt támasztják alá, hogy a település növekedésével szemben a közösséggé formálódás meglehetősen hosszú folyamat, és láthatólag az üteme nem tud lépést tartani a lélekszám gyarapodásával.

Tanulságos azt is megvizsgálni, mennyire szóródnak az egyes típusokhoz sorolt települések értékei, ezt az ábra mellett táblázatban is számszerüsítettük (1. táblázat).

\section{TÁBLÁZAT}

Nonprofit szervezetek a hazai kisvárosok különbözö típusaiban (Nongovernmental Organisations in Different Types of Inland Villages)

\begin{tabular}{|c|c|c|c|c|c|c|}
\hline \multirow{3}{*}{ Típus } & \multicolumn{2}{|c|}{ Városok } & \multicolumn{2}{|c|}{$\begin{array}{c}1000 \text { före jutó } \\
\text { nonprofit szervezet }\end{array}$} & \multicolumn{2}{|c|}{$\begin{array}{l}1000 \text { före jutó non- } \\
\text { profit szervezetek } \\
\text { változásának }\end{array}$} \\
\hline & $\begin{array}{l}s z a ́- \\
m a\end{array}$ & $\begin{array}{l}\text { átlagnépes- } \\
\text { sége }\end{array}$ & száma & szórása & aránya & szórása \\
\hline & 2010 & 2008 & \multicolumn{2}{|c|}{2008} & \multicolumn{2}{|c|}{ 1999-2008 } \\
\hline imázsváros & 7 & 3186 & 9,91 & 3,93 & 0,57 & 0,29 \\
\hline fürdőváros & 17 & 5871 & 8,96 & 4,01 & 0,25 & 0,37 \\
\hline $\begin{array}{l}\text { „valódi” } \\
\text { kisváros }\end{array}$ & 72 & 13079 & 7,44 & 2,17 & 0,28 & 0,23 \\
\hline $\begin{array}{l}\text { intézményvá- } \\
\text { ros }\end{array}$ & 26 & 15178 & 6,79 & 1,26 & 0,41 & 0,18 \\
\hline $\begin{array}{l}\text { „céges” vá- } \\
\text { ros }\end{array}$ & 15 & 6644 & 6,71 & 2,16 & 0,25 & 0,20 \\
\hline $\begin{array}{l}\text { mikrotérségi } \\
\mathrm{kp} \text {. }\end{array}$ & 62 & 4548 & 6,68 & 3,30 & 0,32 & 0,34 \\
\hline rozsdaváros & 11 & 12400 & 5,83 & 1,09 & 0,27 & 0,12 \\
\hline óriásfalu & 17 & 6441 & 5,32 & 1,44 & 0,36 & 0,25 \\
\hline alvóváros & 62 & 9849 & 5,08 & 1,59 & 0,14 & 0,32 \\
\hline kisvárosok & 289 & 9331 & 6,61 & 2,73 & 0,33 & 0,29 \\
\hline
\end{tabular}

Forrás: Saját számítás.

A 2008-as statikus értékben a magas átlaggal rendelkező, egyébként egyenként kis elemszámú csoportok (imázs- és fürdővárosok) jelentős szórást is mutattak, 
amely a dinamikus mutató esetén már nem feltétlenül igaz. Talán a leginkább tanulságos, hogy némely csoport kifejezetten kompakt jelleget mutat. Az intézményvárosok, a rozsdavárosok és az óriásfalvak esetében mondható el, hogy mindkét érték szórása jelentősen elmarad a kisvárosi átlagtól. Ez arra utal, hogy a tipizálás ezekben az esetekben olyan csoportokat hozott létre, amelyek a nonprofit aktivitás szempontjából homogének, más megfogalmazásban ezekre a tényezőkre nézve adekvátak ezek a típusok.

Feltünő továbbá, hogy nem csak abszolút, hanem relatív értelemben is milyen kevés különbséget fedezhetünk fel a szervezetek számának gyarapodásában. Többé-kevésbé úgy tünik, hogy a nonprofit szféra egyenletes ütemben gyarapodik, vagy legalábbis az ebben feltárható különbségek nem függnek a települések típusától. A legjelentősebb különbség a szélső pontokat tekintve az alvóvárosok esetében van, és az átlagos szórás is viszonylag magas itt - egybevágva azzal, amit a térképi ábrázolás már sugallt, nevezetesen, hogy ezek a települések képezik a leginkább dinamikus csoportot.

\section{Összefoglalás}

A kisvárosok civil szervezeteinek vizsgálata számos tanulsággal szolgál. Először is, az intézményesült nonprofit szféra mérete nem látszik alátámasztani azt a feltételezést, hogy a kisvárosok a társadalom önszerveződésének ideális terepei. E tekintetben beilleszkednek abba a sorba, amely a községektől Budapest felé haladva egyre nagyobb fajlagos szervezetszámmal jellemezhető. Még a típusosnak tekinthető, a fentiekben „valódi”-nak nevezett, a kategórián belül viszonylag nagyobb és központosultabb települések is csak szerény mértékben haladják meg a teljes vizsgált minta átlagait.

A kisvárosok szintjén a nonprofit aktivitás a statisztikai módszerekkel nem vizsgálható lokális tényezőkön túl földrajzi és genetikai-funkcionális tényezőkkel egyaránt kapcsolatban van, igaz, csak némely esetben tekinthető ez az összefüggés szorosnak, a különbségeket érdemben magyarázónak. A kisvárosok sokszínű csoportján belül az átlagot képviselö többséghez képest a specializáltabb, egyedi tényezők mentén várossá váló települések képviselik a jelentősebb eltéréseket, mind pozitív, mind pedig negatív irányban. Összességében azonban a civil szféra még a statisztikai elemzések általánosítható szintjén is meglehetősen egyedi mintázattal rendelkezik, vizsgálata elsősorban csak lokális szintü empirikus vizsgálatok révén tárható fel akár csak közelítő pontossággal is.

\section{Irodalom}

Beluszky P.-Győri R. (2006) Ez a falu város! (Avagy a városi rang adományozásának gyakorlata és következményei 1990 után) - Tér és Társadalom. 2. 65-81. o.

Bucher E. (2008) A civil szervezetek szerepe a területfejlesztés intézményrendszerének területi szintjein. - László M.-Bucher E. (szerk.) A terület-és településfejlesztés társadalomföldrajzi megközelítésben. Geographica Pannonica Nova 4. Imedias Kiadó, Pécs. 47-69. o. 
Dövényi Z. (2008) A törpevárosról. - Csapó T.-Kocsis Zs. (szerk.) Nagyközségek és kisvárosok a térben. Savaria University Press, Szombathely. 209-216. o.

Habermas, J. (1993) A posztmodern állapot. Gondolat Kiadó, Budapest.

Kákai L. (2009) Civil szervezetek regionális összefüggései. - Civil Szemle. 1-2. 130-145. o.

Kuti É. (1996) A nonprofit szervezetek szerepe a kilencvenes évek magyar társadalmában és gazdaságában I. - Közgazdasági Szemle. 1. 18-30. o.

László M.-Köszegfalvi Gy. (2007) A településfejlesztés cél- és eszközrendszere. - László M.-Pap N. (szerk.) Bevezetés a terület- és településfejlesztésbe. Lomart Kiadó, Pécs.

Nárai M. (2003) Civil szervezetek egy kisváros életében. - Tér és Társadalom. 1. 91-115. o.

Pirisi G. (2009a) Differenciálódó kisvárosaink. - Földrajzi Közlemények. 3. 313-325. o.

Pirisi G. (2009b) Kisvárosok differenciált átalakulása az ezredforduló Magyarországán. PhD-értekezés. PTE Földtudományok Doktori Iskola, Pécs.

Pirisi G.-Trócsányi A. (2006) Átalakuló kisvárosok a Dél-Dunántúlon. - Földrajzi Értesítő. 1-2. 87-108. o.

Rechnitzer J. (1998) Nonprofit szervezetek területi szerkezete. - Kurtán S.-Sándor P.-Vass L. (szerk.) Magyarország évtizedkönyve 1988-1998. Demokrácia Kutatások Magyar Központja Alapítvány, Budapest. 539-553. o.

Tönnies, F. (1983) Közösség és társadalom. Gondolat Kiadó, Budapest. 9-57. o. 


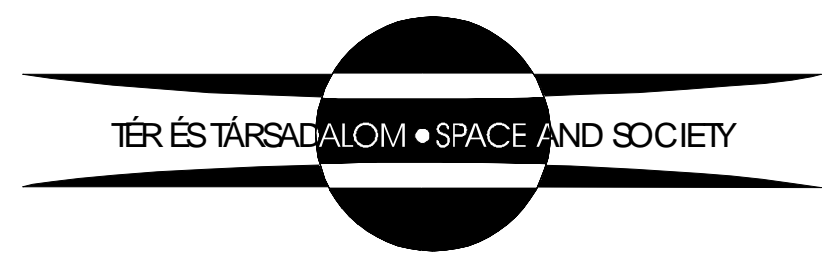

